\title{
APPLICATION OF CROP MODELLING TO PORTUGUESE VITICULTURE: IMPLEMENTATION AND ADDED-VALUES FOR STRATEGIC PLANNING
}

\author{
APLICAÇÃO DA MODELAÇÃO DE CULTURAS À VITICULTURA PORTUGUESA: \\ IMPLEMENTAÇÃO E VALOR ACRESCENTADOS PARA O PLANEAMENTO ESTRATÉGICO
}

\author{
Ricardo Costa $^{1}$; Helder Fraga ${ }^{1}$; Aureliano C. Malheiro ${ }^{1}$; João A. Santos ${ }^{1}$ \\ ${ }^{1}$ Centre for the Research and Technology of Agro-Environmental and Biological Sciences, Universidade de Trás-os-Montes e Alto Douro, 5000- \\ 801 Vila Real, Portugal
}

*corresponding author: Tel: +351259350389, fax: +351259350480, e-mail: hfraga@utad.pt

(Received 11.02.2015.Accepted 20.07.2015)

\section{SUMMARY}

Grapevine (Vitis vinifera L.) is a very important crop in Portugal, where the viticultural sector plays a central role in the national economy. The present study provides a review of most relevant research on grapevine modelling, giving particular emphasis to its past and future applicability to Portuguese conditions. A brief overview of the national sector, as well as of the prevailing physical and biological environments and viticultural practices is provided. Further, the terroir concept is discussed in view of the main controlling factors of grapevine development. Several crop models, either statistical or dynamic, that have reliably simulated grapevine/vineyard parameters, such as phenology, yield and quality, are referred. Statistical models are based on statistically significant relationships between a number of predictors and a given grapevine parameter. Dynamic crop models simulate plant growth and development and holistically integrate crop phenotype, soil profiles, weather and climate data and management practices in their simulations. Dynamic crop models are then becoming important decision support systems in viticulture. Additionally, they allow testing the effects of soils, management decisions and weather on crops. However, only a few dynamic models can properly simulate grapevine performance. Several studies also apply crop models under future conditions to assess the detrimental climate change impacts on grapevines. These crop models can be either applied to real-time monitoring and short-range predictions or to develop long-term climate change projections for the Portuguese viticulture. These studies will represent important added-values for the competitiveness and future sustainability of the winemaking sector in Portugal.

\section{RESUMO}

A videira (Vitis vinifera L.) é uma cultura de grande relevo em Portugal, onde o sector vitivinícola desempenha um papel central na economia nacional. O presente estudo fornece uma revisão de pesquisas mais relevantes sobre a modelação da videira, dando especial ênfase à sua aplicabilidade às condições específicas portuguesas. É dada uma visão sucinta do sector nacional, bem como das condições físicas, biológicas e práticas vitivinícolas predominantes. O conceito de terroir é discutido tendo em conta os principais fatores condicionantes do desenvolvimento da videira. São referidos vários modelos de culturas, estatísticos e dinâmicos, que têm simulado com sucesso as características da videira/vinha, fenologia, produtividade e qualidade. Os modelos estatísticos são baseados em relações estatisticamente significativas entre um número de preditores e uma determinada característica da videira. Os modelos dinâmicos simulam o crescimento e desenvolvimento da planta de forma holística, integrando nas suas simulações o fenótipo da cultura, perfis de solo, dados meteorológicos e práticas culturais. Por este motivo, os modelos dinâmicos estão a tornar-se importantes sistemas de apoio à decisão em viticultura. Além disso, permitem prever os efeitos do solo, das práticas culturais e da meteorologia nas culturas. No entanto, apenas alguns modelos dinâmicos conseguem simular adequadamente o desempenho da videira. Vários estudos também aplicam modelos de cultura para condições futuras para avaliar os impactos das mudanças climáticas sobre a vinha. Estes modelos podem ser aplicados quer na monitorização e previsão de curta duração, quer no desenvolvimento de cenários de alterações climáticas para a viticultura portuguesa. Estes estudos representarão um importante valor acrescentado para a competitividade e sustentabilidade futura do setor vitivinícola em Portugal.

Key words: Crop models, Vitis vinifera, viticulture, climate change.

Palavras-chave: Modelos de culturas, Vitis vinifera, viticultura, alterações climáticas.

\section{CHARACTERIZATION OF PORTUGUESE VITICULTURE}

The present study provides a succinct review of the Portuguese viticulture and addresses the application of crop models as key decision supporting systems

\section{9}

This is an Open Access article distributed under the terms of the Creative Commons Attribution License (http://creativecommons.org/licenses/by/4.0), which permits unrestricted use, distribution, and reproduction in any medium, provided the original work is properly cited. 
towards a more competitive, efficient and sustainable viticulture, under current and future climates.

\subsection{The sector}

All around the world, viticulture and winemaking are very important activities with relevant impacts on local and regional economies. For the specific case of Portugal, which is the 11th wine producer and the 10th wine exporter in the world (OIV, 2013), viticulture and the winemaking socioeconomic sector play a key role in its economic growth. The vineyard area in Portugal is over 229 kha, with an annual wine production of about 6.7 Mhl (OIV, 2013). Portugal exports almost half of its total national wine production. Table wines represent $55 \%$ of the total national exports, followed by DO wines with 36\%, which include fortified wines, such as Port wine as well as Regional wines with $12 \%$. These exports have a large impact on the local economies, accounting for nearly $2 \%$ of national export income (IVV, 2013).

Portugal is divided in 14 viticultural regions (mainland Portugal, Azores and Madeira), with 25 Denominations of Origin - DO (Figure 1). The most important winemaking regions are Douro/Porto, Minho ("Vinho Verde"), Alentejo and Lisboa. In terms of production, Douro/Porto is the main region, with almost $1.5 \mathrm{Mhl}$ in 2013, approximately corresponding to $25 \%$ of all wine produced in Portugal (IVV, 2013). This region has also the largest vineyard area in the country (ca. $45 \mathrm{kha}$ ). Alentejo is, however, the highest yielding region, with an average production of $49 \mathrm{hl} / \mathrm{ha}$, followed by Península-deSetúbal, with $47 \mathrm{hl} / \mathrm{ha}$, and Lisboa, with $38 \mathrm{hl} / \mathrm{ha}$ (2013 estimates).

\subsection{The physical and biological environment}

Portuguese winemaking regions commonly present very specific environmental and climatic characteristics. Portuguese climates show prevailing Mediterranean-like characteristics, with warm dry summers and wet autumn-winter periods. The Portuguese warm-dry summers critically limit crop growth, mainly due to summertime low water availability (Fraga et al., 2014c). Furthermore, extreme winter/spring weather events, such as hail and frost, tend to occur in some northern regions and to infringe important damages to this crop. In general, Portugal presents higher temperatures in the south (e.g. Alentejo) and lower temperatures in the north (e.g. Minho and Douro/Porto) (Figure 2a). The lowest temperatures are found in the mountainous areas of the northern half of the country. With respect to precipitation (Figure 2c), Portugal presents the highest amounts in the northwest and the lowest amounts in its southernmost part. Concerning temperatures and precipitation during the growing season (April-October; Figure 2b and d), similar spatial patterns to the yearly average and cumulative totals are found, but with much lower amounts in precipitation, as it mostly falls in the winter half of the year, a typical feature of the Mediterranean climates.

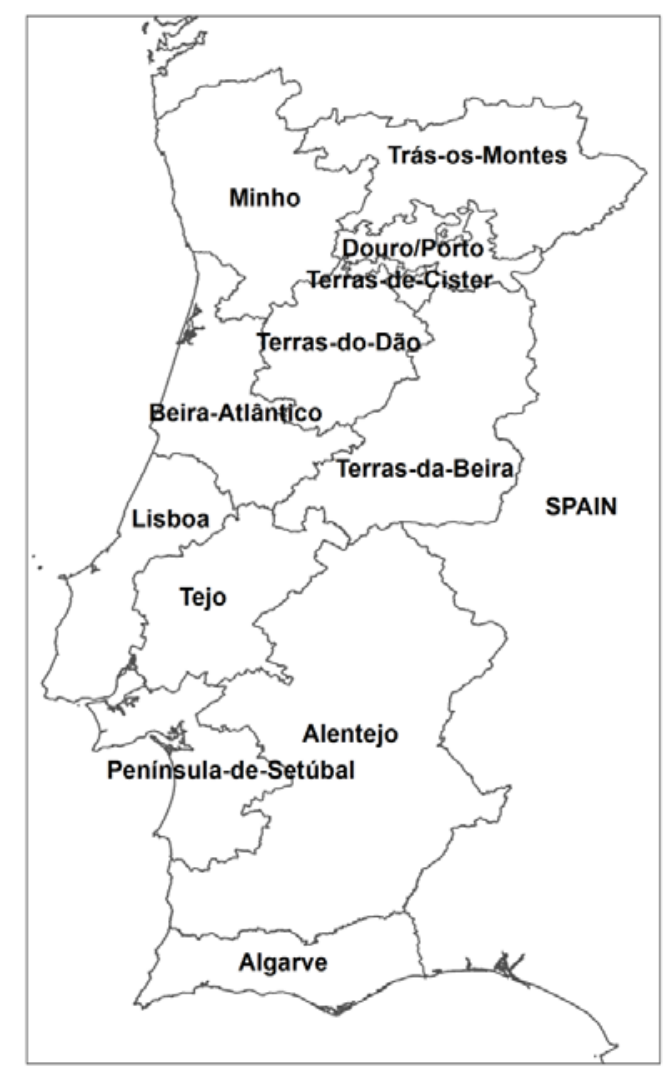

Figure 1. Wine regions in mainland Portugal.

Regiões vitivinícolas em Portugal Continental

The predominant soils in Portugal (FAO, 2006) are cambisols, mostly in the north, and lithosols/luvisols, in the south (Figure 3a). In the northern half of the country there is a large area of cambisols in Minho, Beiras-Atlântico and Terras-da-Beira, while Douro/Porto predominantly presents lithosols, which has been greatly affected by human activity (anthrosols). In the south, the region of Lisboa also presents cambisols, while Peninsula-de-Setubal and Tejo mostly show podzols. The most representative soil types in Alentejo and Algarve are lithosols and luvisols. With respect to topography (Figure 3b), the most mountainous areas are located in inner-northern Portugal, whereas flatlands and plateaus prevail in coastal and southern areas. 

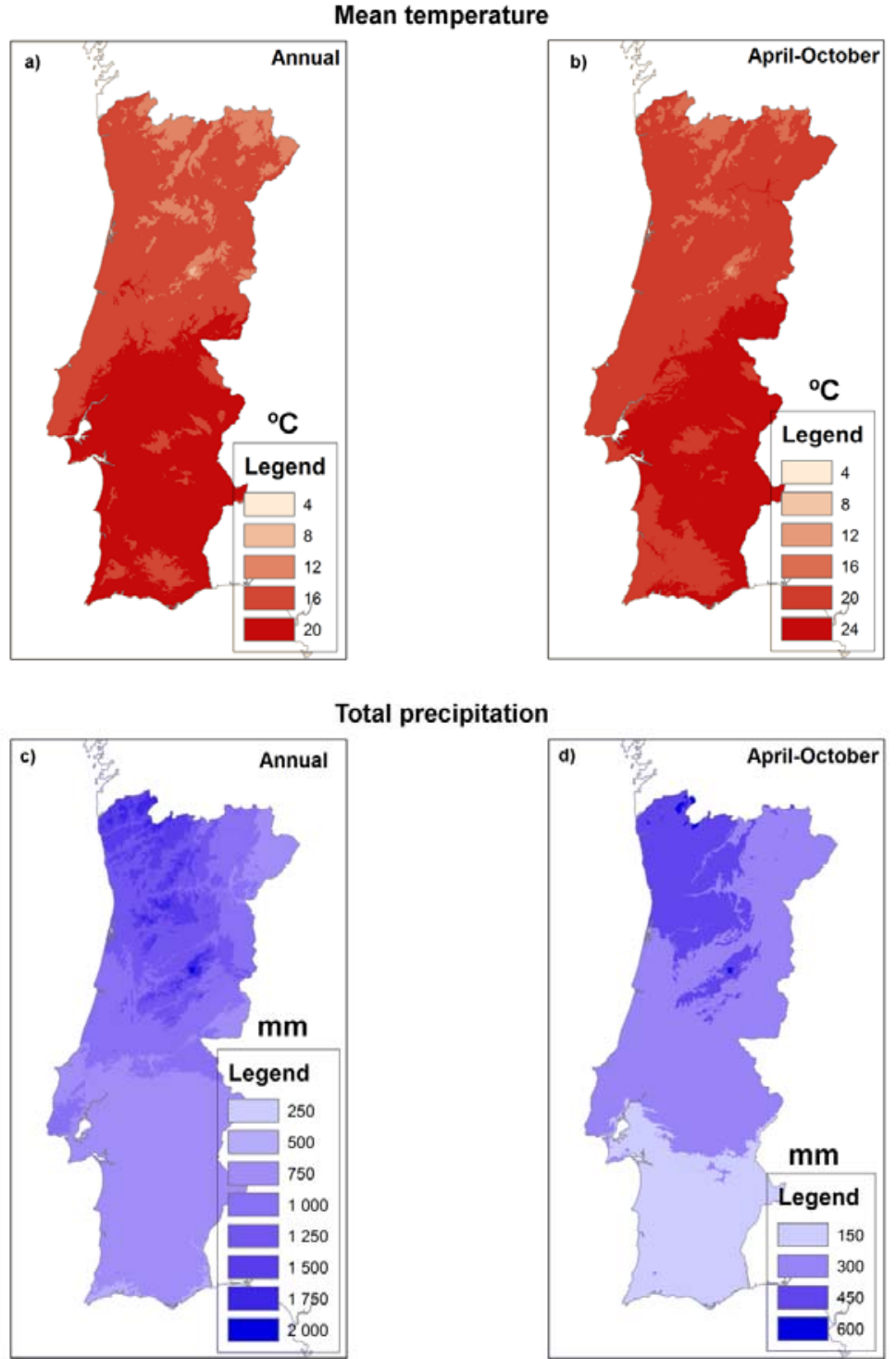

Figure 2. Climate-means for the 1950-2000 baseline of the: a) annual mean temperature; b) April-October mean temperature: c) annual precipitation; d) April-October precipitation in Portugal, calculated using the WORLDCLIM dataset (www.worldclim.org).

Normais climatológicas para 1950-2000 da: a) temperatura média anual; b) temperatura média de Abril-Outubro: c) precipitação anual; d) precipitação de Abril-Outubro em Portugal, utilizando a base de dados WORLDCLIM (www.worldclim.org).

Regarding intraspecific biodiversity, a large number of native varieties can be found in Portugal, according to their adaptation to the different soils, climates and topographic conditions, with red varieties typically predominant in the south and white varieties in the northwest (Fraga et al., 2014b). Some of the most well-known Portuguese winegrapes are: Alvarinho, Castelão, Fernão-Pires, Touriga-Nacional and Touriga-Franca. All these varieties present unique agronomic and oenological characteristics that ultimately result in distinctive wines. They give origin to high quality wines, ranging from the iconic fortified Port wine to the fresh and light "Vinho Verde” (IVV, 2013), which are typically characterized by blending varietals. Therefore, other winemaking regions worldwide are already growing some of these varieties (Anderson, 2014), namely Touriga-Nacional. 

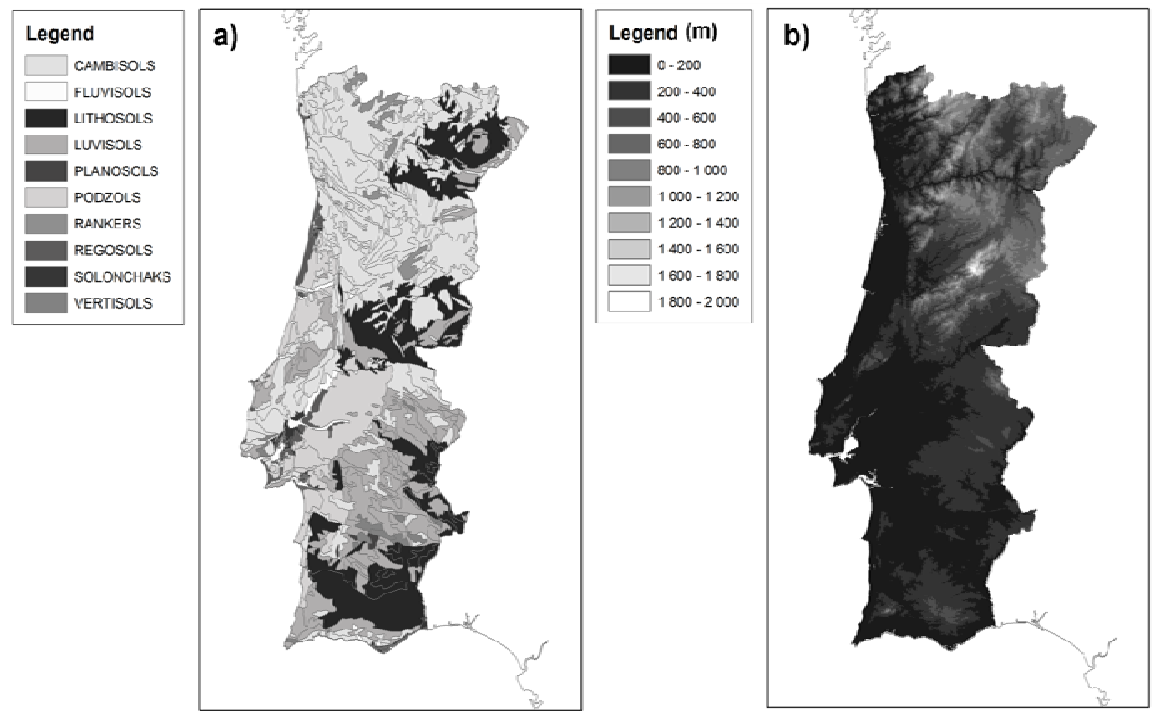

Figure 3. a) Portuguese soils according to the classification system from FAO (2006). b) Elevation in meters over mainland Portugal (source: 'Atlas do Ambiente'; http://sniamb.apambiente.pt/).

a) Solos portugueses de acordo com a classificação FAO (2006). b) Elevação em metros sobre Portugal continental (Fonte: 'Atlas do Ambiente'; http://sniamb.apambiente.pt/).

Regarding the main phenological stages (Real et al., 2014), though depending on the grapevine varieties and environmental conditions in a given year, budburst occurs annually from March to April (Figure 4). It is then followed by a phase of intensive growth until flowering that generally occurs in May-June. Immediately after flowering, the number of potential, and viable fruits, is determined. This stage is followed by the veraison that initiates the grapevine ripening, usually in July-August. Full maturity is then reached, typically in September to October (Magalhães, 2008). At the end of the developing season, the grape clusters are harvested and finally leaves begin to fall, initiating the dormancy stage. Cultural practices have also several particularities in each region. As an example, in Douro/Porto, due to steep slopes, walled terraces are common. Regarding the training systems, the cordon (unilateral and bi-lateral) prevails, though 'pergola' (in Minho) and 'gobelet' (e.g. Alentejo) can also be found. In this way, vine training determines density, orientation and microclimate of the vines.

\section{FACTORS OF INFLUENCE IN VITICULTURE}

A highly complex and interactive system, formed by climate, soil and management practices, greatly influences grapevine development (Magalhães, 2008). This system evolved towards a concept of terroir defined as "an area in which collective knowledge of the interactions between the identifiable physical and biological environment and applied vitivinicultural practices develops, providing distinctive characteristics for the products originating from this area” (OIV, 2010). All these terroir elements strongly influence growth and development of the different varieties of Vitis vinifera L. (van Leeuwen et al., 2004; van Vaudour et al., 2010; Yau et al., 2013; Fraga et al., 2014b), as well as wine type, yield and quality.

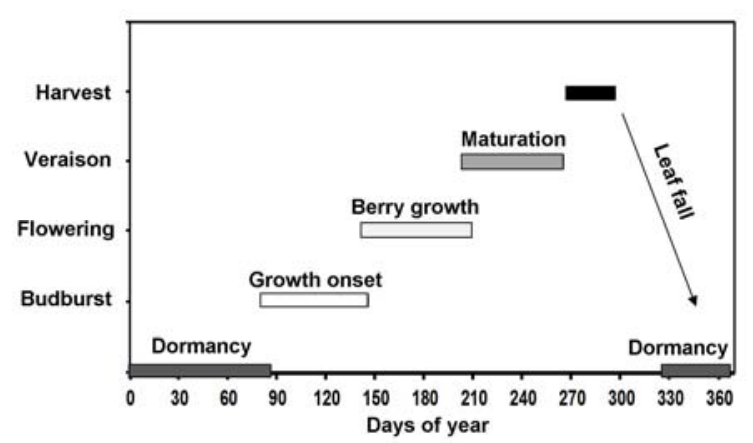

Figure 4. Typical grapevine annual growth cycle and phenological stages in Portugal.

Ciclo de crescimento anual típico e estados fenológicos da videira em Portugal

Climate is considered the main element of terroir (Jones and Davis, 2000; Carbonneau, 2003; van Leeuwen et al., 2004). One of the most important 
climatic thresholds is the classical $10{ }^{\circ} \mathrm{C}$ base temperature for budburst (Winkler, 1974). In fact, temperature conditions drive the timing and length of all grapevine phenological stages (Kose, 2014), thus also affecting the inter-annual variability in yield, production and quality (de Orduna, 2010; Fraga et al., 2014d). Berry colour, flavour and aroma, tannin and sugar levels are also affected by temperature at ripening (Jones and Davis, 2000; Malheiro et al., 2010). Precipitation is another important element, which widely controls soil water availability affecting grapevine water use (Ferreira et al., 2012). Overall, high-quality wines are associated to moderate water stress during maturation (Koundouras et al., 1999; van Leeuwen et al., 2004; Storchi et al., 2005). A severe water stress during early stages may considerably delay growth and grapevine development (Hardie and Considine, 1976). On the other hand, excessive vigour, diseases and other problems negatively affecting wine quality may occur when excessive soil moisture is verified over the growing season (During, 1986; Magalhães, 2008). Extreme weather events, such as late spring frosts, hail and heat waves (above $35{ }^{\circ} \mathrm{C}$ ), may severely damage grapevine leaves and berries (e.g. sunscald) and are a significant risk to this crop (Trought et al., 1999; Chuine et al., 2004; Molitor et al., 2014).

Soil is another important factor for viticulture and is an important part of the terroir concept (Magalhães, 2008). Soils are composed by organic and inorganic materials and a source of water and nutrients (e.g. nitrogen) that are crucial for grapevine physiology, growth and yield attributes (Winkler, 1974; Morlat and Jacquet, 2003). In fact, grapevine composition can be influenced by soil structure and chemistry and can thereby affect wine quality (Mackenzie and Christy, 2005). Vineyard installation is usually preferred in deep soils with good drainage, either natural or manmade. Root growth and development is limited in compact and shallow soils that can obstruct their access to oxygen, water and nutrients (Jackson and Lombard, 1993). Soil water holding properties are also essential, as they can have an effect on grapevine performance (Field et al., 2009; Yau et al., 2013).

Topographic elements are another important factor. Elevation, slope and aspect are very relevant in viticulture (Jones et al., 2004; Yau et al., 2013). Elevation influences temperatures on vineyards (through the vertical temperature gradient), exerting this way a strong influence in site and varietal selection (Magalhães, 2008). Slope degree affects grapevines through solar exposure, thus having an impact on canopy microclimate, soil erosion, water drainage and viticultural management (Zsofi et al., 2011).

The quality and growth of grapevines can also be influenced by management practices, such as the choice of rootstock and scion, training systems, crop load, pruning type and cultural timings (Winkler, 1974). Knowledge of the varietal specificities allows optimizing viticultural practices and is required for production of high quality wines (Jones and Davis, 2000). Additionally, oenological practices also greatly affect wine quality (Unwin, 1996).

\section{CROP MODELS IN VITICULTURE}

Many studies have been undertaken in order to identify statistical relationships between grapevine parameters and the abovementioned terroir factors. These relationships are often rendered in crop models, which have proven to be useful in predicting yields, phenology, berry development and biomass. Crop model simulations integrate current scientific knowledge from many different areas, including crop physiology, climatology/agrometeorology, plant breeding, agronomy, soil physics/chemistry and pathology. Given the growing awareness for the need to implement these types of models, several international projects have been created with this aim, such as the MACSUR (Modelling European Agriculture with Climate Change for Food Security) or the AgMIP (Agricultural Model Intercomparison and Improvement Project) project. Crop models can be either statistical or dynamic in their formulation. Statistical models are computationally cheaper than dynamic models, but may present inconsistencies among variables (Shin et al., 2009). These weaknesses may happen mainly during non-linear crop-environment interactions that cannot be properly resolved by statistical approaches. As dynamic methods holistically integrate the different environmental interactions, they have the potential to outperform statistical techniques. Nevertheless, statistical models may still be a very useful tool when neither dynamic models nor sufficient computing resources are available (Shin et al., 2009). A more detailed discussion of these models is presented in the following sections.

\subsection{Statistical crop models}

A statistical model establishes relationships between variables in the form of mathematical equations (McCullagh, 2002). These models usually use historical data of grapevine (or other crop) attributes as dependent variables, while the terroir elements act as independent variables (Lobell and Burke, 2010). Those models allow simulating e.g. grapevine yield 
(Williams et al., 1985; Nemani et al., 2001; Lobell et al., 2006; Quiroga and Iglesias, 2009), wine quality (Jones et al., 2005; Moriondo et al., 2011), grapevine growth and development (Schultz, 1992; Bindi et al., 1997; Jones and Davis, 2000; Lopes and Pinto, 2005), water stress conditions (Pellegrino et al., 2006) and risk of pests/diseases (Calonnec et al., 2008).

Regarding yield and quality, some studies have been accomplished to identify statistical relationships between grapevine yield and some environmental variables. For the Portuguese Douro/Porto and Minho regions, statistically significant relations between grapevine yield and monthly mean temperatures or precipitation totals were found (Santos et al., 2011; Santos et al., 2013; Fraga et al., 2014d). These studies demonstrated that anomalously high March rainfall (during budburst), as well as anomalously high temperatures and low precipitation in May and June (flowering and berry development) are needed to achieve moderate-to-high production. Cunha et al. (2010) developed a forecast model for evaluating the annual variability in regional wine yield based on remote sensing indices in vineyards in Alentejo, Minho and Douro. For the latter region, Gouveia et al. (2011) developed a vintage model using climatic and remote sensing data. Cunha et al. (2003) also demonstrated that it is possible to obtain early season estimates of wine production using grapevine airborne pollen concentrations as a predictor.

Still focusing on yield or quality attributes, similar results have also been found for other winemaking regions worldwide. Rovira-Más and Sáiz-Rubio (2013) applied crop metrics (e.g. vegetation amount, berry size, grape yield, elevation, soil compaction and $\mathrm{pH})$ to predict grapevine yield. In another study, Webb et al. (2008b) modelled the climatic sensitivity of premium quality grapevines by developing grapevine quality-temperature models for varieties grown in Australia. Through a statistical approach it was possible to identify key phenological periods influencing phenolic concentration at maturity for Pinot noir (Nicholas et al., 2011). The authors demonstrated that warm temperatures from budburst to flowering increase phenolic concentrations, which are beneficial for wine quality.

Regarding phenology, several studies identified statistically significant relationships with climate. The standard growing degree-day (GDD) model measures accumulated temperatures above $10^{\circ} \mathrm{C}$ (Winkler, 1974) and is commonly used for evaluating grapevine phenology (Winkler, 1974; Moncur et al., 1989; Oliveira, 1998; Jones and Davis, 2000; Chuine et al., 2003; van Leeuwen et al., 2008; Duchene et al., 2010; Parker et al., 2011). In Portugal, Lopes et al.
(2008) estimated the usefulness of these thermal models for several grapevine varieties in the Lisboa wine region. For the Portuguese Douro/Porto region, Real et al. (2014) also demonstrated their reliability on monitoring phenology, despite the need for local calibrations. For the Lisbon region, Malheiro et al. (2013) and Fraga et al. (2014a) applied a linear regression models to show that phenological timings are deeply tied to air temperatures and remote sensing indices. Many other studies assessing relationships between air temperature, remote sensing indices and grapevine phenology have been conducted worldwide (Williams et al., 1985; Chuine et al., 2003; de Cortazar-Atauri et al., 2009; Caffarra and Eccel, 2010; Bock et al., 2011; Cunha and Richter, 2012; Fila et al., 2012; Parker et al., 2013; Rodrigues et al., 2013).

Concerning vineyard water management, few studies have been devoted to Portugal, while some advances have been made in other winemaking regions in Europe (Lebon et al., 2003; Berdeja et al., 2014; Pellegrino et al., 2014; Roux et al., 2014; Schreiner and Lee, 2014). Pellegrino et al. (2006) used a simple soil water balance model, specifically parameterised for grapevine, to characterize soil water deficits on 24 fields within 4 vineyards in Mediterranean southern France. A similar approach was carried out by Gaudin et al. (2014), using a water balance model to classify water stress in French Mediterranean vineyards. In preparation of a water stress alert system, Salinari et al. (2014) developed a water stress model to early detect the best management options as a function of soil water content.

Statistical models have also been developed to estimate the risk of pests and diseases, while none was carried out in the Portuguese vineyards to our knowledge. Caffarra et al. (2012) modelled the impact of insect pests on the eastern Italian Alps. Calonnec et al. (2008) used an epidemiological model to simulate the dynamics of the powdery mildew pathogen affecting the viticultural production systems, while Hoppmann and BerkelmannLoehnertz (2000) used phenological models to establish suitable plant protection regimes. However, on the whole, the number of statistical models applied to pests or diseases is relatively small compared to other parameters.

\subsection{Dynamic crop models}

Dynamical crop models simulate/monitor plant growth and development on a daily basis and at a given location. These models integrate crop phenotype, soil profiles, weather data and management options in their simulations. Sitespecific parameters for climate, soil, plants and crop 
management, among others, are defined as input in model runs (Figure 5). Weather data, such as maximum and minimum near-surface temperatures, rainfall and incoming solar radiation are updated on a daily basis, while other parameters are generally kept invariant throughout the model run (e.g. soils parameters). Dynamic crop models are becoming important decision support systems for monitoring crops and for assessing the impact of soils, management decisions, weather and climate change on crops (Paz et al., 2007; Semenov and DoblasReyes, 2007; Challinor and Wheeler, 2008). In fact, the simulation of crop parameters under different conditions, scenarios and stresses are key outcomes from crop models. Although many models have been applied to evaluate crop development and growth, only a few can properly simulate grapevine systems (Valdes-Gomez et al., 2009).

Applied to viticulture, dynamic crop modelling can be either focused on the simulation of a particular process or on the entire plant growth (Moriondo et al., 2015). As an example of the simulation of a particular process, Lebon et al. (2003) used a dynamic model to simulate the seasonal dynamics of soil water balance on vineyards, demonstrating that this process can be adequately replicated by the model. In another study, Nendel and Kersebaum (2004) skilfully simulate nitrogen dynamics in vineyard soils using the NVINE model. Ben-Asher et al. (2006) assessed the skill of the SWAP (soil, water, atmosphere and plant) model to estimate the salinity effects in grapevine production. Their results demonstrate that the model can generate realistic responses to salinity when water quality is the only variable used. To help choose adequate training and pruning strategies, Poni et al. (2006) used the STELLA software to build a model to predicting the daily carbon balance and dry matter accumulation on grapevine vertical shoots. The Walis model was evaluated by Celette et al. (2010) to simulate water partitioning on a intercropped vineyard. Webb et al. (2007) used the VineLOGIC model (Godwin et al., 2002) to determine grapevine phenology. A broader approach was developed by Cola et al. (2014), which developed a new dynamic model MoDeM_IVM DSS (Monitoring and Decision Making in Integrated Vineyard Management Decision Supporting Systems) for predicting grapevine seasonal dynamics, sourcesink balance and yield, showing high potential for its inclusion in viticultural decision supporting systems and technical assistance.

An example of a dynamic crop model that can be used to simulate the whole plant growth process is the STICS (Simulateur mulTIdisciplinaire pour les Cultures Standard) (Brisson et al., 2003). STICS was developed by the French National Institute for Agronomic Research (INRA), comprising a large multidisciplinary community of researchers, from microclimate and soils to crop sciences (Brisson, 2004). This is a generic crop model that can be applied to a wide variety of crops, such as wheat (Brisson et al., 2002; Rodriguez et al., 2004), maize (Bruckler et al., 2000; Brisson et al., 2002; Debaeke, 2004), sugarcane (Valade et al., 2014) and banana (Brisson et al., 1998) and for many other purposes such as irrigation strategies (Katerji et al., 2010), carbon balances (de Noblet-Ducoudre et al., 2004), soil drainage (Tournebize et al., 2004) and nitrate contamination (Ledoux et al., 2007; Jego et al., 2008) and climate change impact assessment (Courault and Ruget, 2001; Juin et al., 2004; Gonzalez-Camacho et al., 2008). de Cortazar-Atauri (2006) adapted this model for grapevines assessing the necessary parameterizations. STICS is one of the few freely available and well-documented crop models integrating grapevine, a short overview of its applications to viticulture will be presented henceforth.

STICS runs on a daily time-step and variables related to climate, soil and crop system are used as input (Brisson et al., 2003). It simulates the whole processes of crop growth and development, also including water and nitrogen balances (Figure 5). As output, it provides variables related to yield and development parameters. The model dynamics is described as follows (de Cortazar-Atauri, 2006; Brisson et al., 2008):

1 - Phenology is modelled by temperature accumulation;

2 - Fruit growth is defined by the dynamics of dry matter accumulation and water content;

3 - Dry matter content is computed using thermal time and potential final dry weight;

4 - Dry matter partitioning is calculated through the sink strength of several types of plant organs;

5 - The harvest date is determined according to berry water content, which is greatly correlated with sugar content;

6 - Soil water balance results from precipitation, irrigation and soil evaporation, while crop transpiration is estimated from the energy balance, which is constrained by soil water availability, drainage and run-off;

7 - Grape berry water content dynamics is modelled by berry growth and plant water status; 
8 - Plant water stress is calculated based on crop demand and water supply, which influences leaf area and consequently light interception and net assimilation rate (Pellegrino et al., 2005), with implications on grape sugar concentrations (Pellegrino et al., 2006);
9 - Light intercepted by vines is evaluated using a simple geometrical approach, by separating diffuse and direct radiation components.

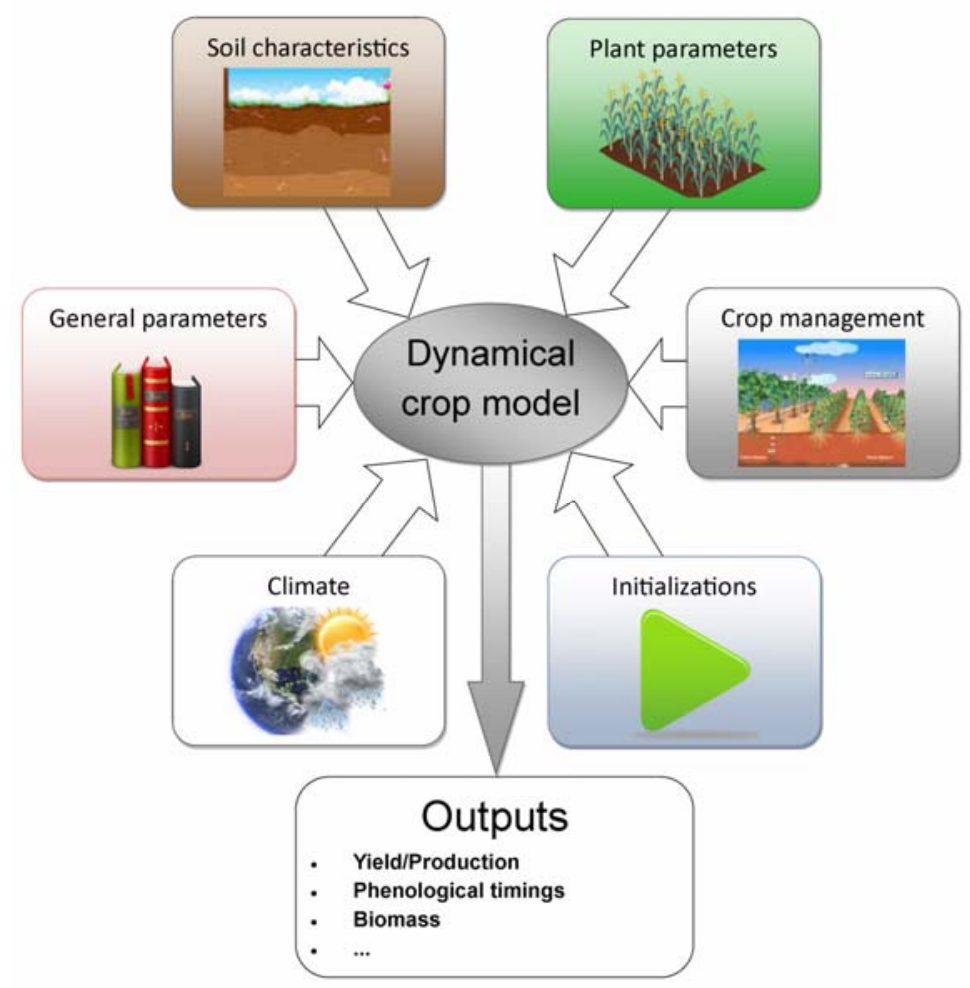

Figure 5. Representation of a dynamic crop model, main parameterization categories and output variables.

Representação do modelo cultural dinâmico, categorias principais de parametrização e variáveis de saída.

Focusing on grapevines, STICS has been used for simulating grapevine yield and quality attributes (Valdes-Gomez et al., 2009), soil water balance (Valdes-Gomez et al., 2011), climate change impact assessment (de Cortazar-Atauri, 2006), crop practices (Brisson et al., 2011), soil management (Brisson et al., 1998) and risks of pests/diseases (Leroy et al., 2013).

Valdes-Gomez et al. (2009) assessed STICS skill in replicating grapevine phenology, yield, soil water content and biomass. Irrigated and non-irrigated vineyards in Chile and France were selected for these simulations. The model showed a high skill in estimating grapevine phenology, with differences between simulated and observed timings less than six days. STICS also reliably simulated grapevine water stress, biomass production and yield. In a subsequent study, STICS allowed simulating water and nitrogen balances (Valdes-Gomez et al., 2011) for the “Cabernet Sauvignon” variety in Chile.

Celette et al. (2008) also assessed STICS ability to represent vineyard water balance in two situations for Chile and France, differing in annual rainfall and in water management practices. Results revealed an accurate estimation of grapevine phenology, as well as of total dry matter production and yield. Soil water content was also well estimated in both situations. Nevertheless, the authors point out that water balance modelling using STICS may not be appropriate in situations with significant surface runoff. These authors also highlighted some modelling uncertainties, namely in the simulation of surface soil layer humidity, which may have a significant effect on nitrogen balance simulation. 
de Cortazar-Atauri (2006) assessed the influences of climate change on French grapevines by coupling STICS with the ARPEGE climate model. This study assesses water balance changes and impacts on production and quality. Results allowed simulating current and future water stress conditions, nitrogen stress, biomass and yield, which may help planning mitigation actions against climate change impacts. In another study, potential climate change impacts on production and phenology were also assessed for two grapevine varieties in Sardinia (Italy) (Muresu, 2012), by coupling climate models with STICS to generate future scenarios. Model performance was also assessed using historical phenology and yield data, showing a high skill.

STICS was also used to assess the environmental impacts of crop fertilization. Ruiz-Ramos et al. (2011) used STICS coupled with a geographic information system to estimate the amount of NO3leaching in La Rioja (Spain). Its performance was examined by comparing simulations and measurements of irrigated vineyards. Using STICS simulations, the authors identified environmentally safe agricultural practices for mitigating NO3pollution. With respect to pests and diseases, Leroy et al. (2013) applied a bioeconomic model, coupled with STICS, to test different fungicide treatment strategies so as to diminish pesticide use in vineyards. In a recent study, Coucheney et al. (2015) evaluated STICS performance for several crops, and found poor performances for $\mathrm{N}$ prediction on vine, that can be due to the fact that the model is more focused on carbon functioning making simpler assumptions on $\mathrm{N}$ simulation.

In Portugal, some studies have been devoted to the application of STICS model to grapevines. Under the SIAMVITIS project (Climate change in Viticulture: Scenarios, Impacts and Adaptation Measures) an initial application of this model was achieved, showing promising results (Coelho et al., 2013; Pinto, 2013). More recently, Fraga et al. (2015), calibrated the STICS model for three of the most important Portuguese varieties (Aragonez, Touriga-Franca and Touriga-Nacional), obtaining a high model skill in the simulation of yield, phenology and water status.

\section{STRATEGIC PLANNING FOR PORTUGAL}

\subsection{Monitoring and short-to-medium range prediction}

Although grapevine production and phenology in Portugal were already skilfully modelled by several statistical approaches, the use of dynamic crop models in Portuguese viticulture is still in very early stages and future research on this topic is essential, particularly taking into account the relevance of this sector to the national economy, as previously described. After these models are properly calibrated and validated for the Portuguese varieties and environmental conditions, they may become useful decision support systems for stakeholders in the national winemaking sector. These models enable the adjustment of all cultural practices for each specific location, such as vineyard intervention dates, plant density, soil and water management, irrigation efficiency and nutrient management. These models may be used to predict annual yields and phenological timings, allowing a more accurate preparation of vineyard activities, such as spray scheduling and harvest planning. Crop models also provide preventive measures on soil conservation options in order to improve tillage, mulching and application of fertilizers. Due to the wide range of different terroirs throughout Portugal, crop models may also allow identifying the most suitable varieties for a given region based not only on their thermal requirements, but also on their tolerance to stress factors, such as high temperatures, drought, pests and diseases. Given the benefits of the application of these types of models to grapevine monitoring and short-to-medium range prediction they are expect to yield efficiency gains at the vineyard level, resulting in higher profit margins for growers.

\subsection{Long-range prediction under climate change}

Climate change projections are expected to have significant impacts on viticulture, mostly owing to changes in the temperature and precipitation patterns (IPCC, 2013). The expected warming and drying trends in southern Europe may bring some additional challenges for grapevine production (Santos et al., 2011). Temperature projections for the main viticultural regions in Europe highlight increases in the growing-season mean temperatures (Duchene and Schneider, 2005; Jones et al., 2005; Neumann and Matzarakis, 2011). This warming leads to longer growing seasons but earlier phenological events (Chuine et al., 2004; Dalla Marta et al., 2010; Bock et al., 2011), which may have harmful impacts on wine quality (Webb et al., 2008a). Some regions are projected to become excessively dry to grapevine production without adequate irrigation (Kenny and Harrison, 1992; Koundouras et al., 1999; Malheiro et al., 2010; Santos et al., 2013). All these factors suggest a general lowering of the suitability of the winemaking regions in southern Europe (Stock et al., 2005; Malheiro et al., 2010; Santos et al., 2012; Fraga et al., 2013). More specifically for Portugal, projections reveal similar changes to other European regions with Mediterranean-like climates (i.e. 
warming and drying trends), which can lead to changes in the suitability of the national viticultural regions (Fraga et al., 2012). Climate change may indeed lead to perceivable changes in traditional wine styles. Furthermore, changes on the frequency and strength of precipitation and temperature extremes are also projected for Portugal (Costa et al., 2012; Andrade et al., 2014).

Crop models are a key tool to determine the impact of climate change on crop growth and to evaluate the potential of new viticultural regions (Webb et al., 2007; Bois et al., 2008; Kwon et al., 2008; Scaglione et al., 2008; Caffarra and Eccel, 2010; Duchene et al., 2010; Caffarra and Eccel, 2011) and to prevent, or minimize, the impact of climate extremes (Molitor et al., 2014). Crop models can also be used to assess carbon sequestration and emissions of other greenhouse gases, assisting the design of mitigation measures in conformity with the 20-20-20 commitments of the EU Directive 2009/28/EC. Only by using crop models is possible to fully integrate all these aspects (Tomasi et al., 2011) and to develop adequate mitigation and adaptation measures for the viticultural sector under a changing climate. Therefore, in forthcoming research, dynamic crop models will be applied to the Portuguese viticultural regions under climate change scenarios.

\section{CONCLUSIONS}

Given the above description, crop models, such as STICS, can then be considered key decision making tools for short- and long-term strategic planning in viticulture. The possibility of obtaining early predictions of production and development will contribute to a more efficient winemaking process. This knowledge is crucial for a timely planning of field activities, such as determining harvest dates, and for achieving premium quality vintages. Furthermore, several studies use crop models to evaluate the impact of climate change on grapevine. Owing to the abovementioned relevance of the viticultural sector to Portugal, it is vital to improve its resilience and future sustainability. The efficiency gains, of the integration of these types of models in the industry, are expected to increase the competitiveness and sustainability of the wine sector in Portugal.

\section{ACKNOWLEDGEMENTS}

This study was supported by national funds by FCT Portuguese Foundation for Science and Technology, under the project UID/AGR/04033/2013. This work was also supported by the project "ModelVitiDouro"
- PA 53774”, funded by the Agricultural and Rural Development Fund (EAFRD) and the Portuguese Government by Measure 4.1 - Cooperation for Innovation PRODER program - Rural Development Programme.

\section{REFERENCES}

Anderson K., 2014. Changing Varietal Distinctiveness of the World's Wine Regions: Evidence from a New Global Database. Journal of Wine Economics, 9(03), 249-272.

Andrade C., Fraga H., Santos J.A., 2014. Climate change multimodel projections for temperature extremes in Portugal. Atmos. Sci. Lett., 15(2), 149-156.

Ben-Asher J., van Dam J., Feddes R.A., Jhorar R.K., 2006. Irrigation of grapevines with saline water: II. Mathematical simulation of vine growth and yield. Agric. Water Manag., 83(1-2), 22-29.

Berdeja M., Hilbert G., Dai Z.W., Lafontaine M., Stoll M., Schultz H.R., Delrot S., 2014. Effect of water stress and rootstock genotype on Pinot Noir berry composition. Aust. J. Grape Wine R., 20(3), 409-421.

Bindi M., Miglietta F., Gozzini B., Orlandini S. and Seghi L., 1997. A simple model for simulation of growth and development in grapevine (Vitis vinifera L) .1. Model description. Vitis, 36(2), 6771.

Bock A., Sparks T., Estrella N., Menzel A., 2011. Changes in the phenology and composition of wine from Franconia, Germany. Clim. Res., 50(1), 69-81.

Bois B., Wald L., Pieri P., van Leeuwen C., Commagnac L., Chew, P., Christen M., Gaudillere J.P. and Saur E., 2008. Estimating spatial and temporal variations in solar radiation within Bordeaux winegrowing region using remotely sensed data. J. Int. Sci. Vigne Vin, 42(1), 15-25.

Brisson N., 2004. Special issue: Crop model STICS (simulateur mulTIdisciplinaire pour les cultures standard). Agronomie, 24(6-7), 293-293.

Brisson N., Gary C., Justes E., Roche R., Mary B., Ripoche D., Zimmer D., Sierra J., Bertuzzi P., Burger P., Bussière F. Cabidoche Y.M., Cellier P., Debaeke P., Gaudillère J.P., Hénault C., Maraux F., Seguin B., Sinoquet H., 2003. An overview of the crop model stics. Eur. J. Agron., 18(3-4), 309-332.

Brisson N., Launay M., Mary B., Beaudoin N., 2008. Conceptual Basis, Formalisations and Parameterization of the STICS Crop Model. 297 p. Editions Quae, Versailles.

Brisson N., Ozier-Lafontaine H., Dorel M., 1998. Effects of soil management and water regime on banana growth between planting and flowering. Simulation using the STICS model. In: Proceedings of the First International Symposium on Banana in the Subtropics, 490, 229-238.

Brisson N., Pieri P., Lebon E., 2011. On the Interest of Introducing Irrigation and Changing Practices Tomorrow in Some French Vineyard Areas. In: VI International Symposium on Irrigation of Horticultural Crops, 889, 167-174.

Brisson N., Ruget F., Gate P., Lorgeau J., Nicoullaud B., Tayot X., Plenet D., Jeuffroy M.H., Bouthie, A., Ripoche D., Mary B., Justes E., 2002. STICS: a generic model for simulating crops and their water and nitrogen balances. II. Model validation for wheat and maize. Agronomie, 22(1), 69-92.

Bruckler L., Lafolie F., Ruy S., Granier J., Baudequin D., 2000. Modelling the agricultural and environmental consequences of non- 
uniform irrigation on a maize crop. 1. Water balance and yield. Agronomie, 20(6), 609-624.

Caffarra A., Eccel E., 2010. Increasing the robustness of phenological models for Vitis vinifera cv. Chardonnay. Int. J. Biometeorol., 54(3), 255-267.

Caffarra A., Eccel E., 2011. Projecting the impacts of climate change on the phenology of grapevine in a mountain area. Aust. $J$. Grape Wine R., 17(1), 52-61.

Caffarra A., Rinaldi M., Eccel E., Rossi V., Pertot I., 2012. Modelling the impact of climate change on the interaction between grapevine and its pests and pathogens: European grapevine moth and powdery mildew. Agric. Ecosyst. Environ., 148, 89-101.

Calonnec A., Cartolaro P., Naulin J.M., Bailey D., Langlais M., 2008. A host-pathogen simulation model: powdery mildew of grapevine. Pl. Pathol., 57(3), 493-508.

Carbonneau A., 2003. Ecophysiologie de la vigne et terroir. In: Terroir, zonazione, viticoltura. Trattato internazionale. 61-102, Phytoline.

Celette F., Ripoche A., Gary C., 2010. WaLIS-A simple model to simulate water partitioning in a crop association: The example of an intercropped vineyard. Agric. Water Manag., 97(11), 17491759 .

Celette F., Valdes H., Gary C., Ortega-Farias S., Acevedo C., de Cortazar I.G., 2008. Evaluation of the STICS model for simulating vineyard water balance under two different water management strategies. In: Proceedings of the Fifth International Symposium on Irrigation of Horticultural Crops, 792, 155-162.

Challinor A.J., Wheeler T.R., 2008. Crop yield reduction in the tropics under climate change: Processes and uncertainties. Agric. For. Meteorol., 148(3), 343-356.

Chuine I., Kramer K., Hanninen H., 2003. Plant development models. In: Phenology - An Integrative Environmental Science, Tasks for vegetation science 39. 217-235. Schwartz M.D. (ed.), Kluwer Academic Publishers.

Chuine I., Yiou P., Viovy N., Seguin B., Daux V., Ladurie E.L., 2004. Historical phenology: Grape ripening as a past climate indicator. Nature, 432(7015), 289-290.

Coelho J.C., Lopes C.M., Braga R., Pinto P.A., Egipto R.J.L., 2013. Avaliação do impacte das alterações climáticas na sustentabilidade económica da cultura da vinha no Alentejo. In: VII APDEA Congress - ESADR 2013, P15, 4015-4039.

Cola G., Mariani L., Salinari F., Civardi S., Bernizzoni F., Gatti M., Poni S., 2014. Description and testing of a weather-based model for predicting phenology, canopy development and sourcesink balance in Vitis vinifera L. cv. Barbera. Agric. For. Meteorol., 184(0), 117-136.

Costa A.C., Santos J.A., Pinto J.G., 2012. Climate change scenarios for precipitation extremes in Portugal. Theor. Appl. Climatol., 108(1-2), 217-234.

Coucheney E., Buis S., Launay M., Constantin J., Mary B., García de Cortázar-Atauri I., Ripoche D., Beaudoin N., Ruget F., Andrianarisoa K.S., Le Bas C., Justes E., Léonard J., 2015. Accuracy, robustness and behavior of the STICS soil-crop model for plant, water and nitrogen outputs: Evaluation over a wide range of agro-environmental conditions in France. Environ. Model. Software, 64(0), 177-190.

Courault D., Ruget F., 2001. Impact of local climate variability on crop model estimates in the south-east of France. Clim. Res., 18(3), 195-204.
Cunha M., Abreu I., Pinto P., de Castro R., 2003. Airborne pollen samples for early-season estimates of wine production in a Mediterranean climate area of northern Portugal. Am. J. Enol. Vitic., 54(3), 189-194.

Cunha, M., Marcal, A.R.S., Silva, L., 2010. Very early prediction of wine yield based on satellite data from vegetation. Int. J. Remote Sens., 31(12), 3125-3142.

Cunha M., Richter C., 2012. Measuring the impact of temperature changes on the wine production in the Douro Region using the short time fourier transform. Int. J. Biometeorol., 56(2), 357-370.

Dalla Marta A., Grifoni D., Mancini M., Storchi P., Zipoli G., Orlandini S., 2010. Analysis of the relationships between climate variability and grapevine phenology in the Nobile di Montepulciano wine production area. J. Agric. Sci., 148, 657-666.

de Cortazar-Atauri I.G., 2006. Adaptation du modèle STICS à la vigne (Vitis vinifera L.). Utilisation dans le cadre d'une étude d'impact du changement climatique à l'échelle de la France. 292.p. $\mathrm{PhD}$ thesis, Montpellier.

de Cortazar-Atauri I.G., Brisson N., Gaudillere J.P., 2009. Performance of several models for predicting budburst date of grapevine (Vitis vinifera L.). Int. J. Biometeorol., 53(4), 317-326.

de Noblet-Ducoudre N., Gervois S., Ciais P., Viovy N., Brisson N., Seguin B., Perrier A., 2004. Coupling the Soil-VegetationAtmosphere-Transfer Scheme ORCHIDEE to the agronomy model STICS to study the influence of croplands on the European carbon and water budgets. Agronomie, 24(6-7), 397-407.

de Orduna R.M., 2010. Climate change associated effects on grape and wine quality and production. Food Res. Int., 43(7), 1844-1855.

Debaeke P., 2004. Scenario analysis for cereal management in water-limited conditions by the means of a crop simulation model (STICS). Agronomie, 24(6-7), 315-326.

Duchene E., Huard F., Dumas V., Schneider C., Merdinoglu D., 2010. The challenge of adapting grapevine varieties to climate change. Clim. Res., 41(3), 193-204.

Duchene E., Schneider C., 2005. Grapevine and climatic changes: a glance at the situation in Alsace. Agron. Sustain. Dev., 25(1), 9399.

During H., 1986. Testing for drought tolerance in grapevine scions. Angew. Bot., 60(1-2), 103-111.

FAO, 2006. World reference base for soil resources 2006, a framework for international classification, correlation and communication. World soil resources reports 103 p. Food and Agriculture Organization of the United Nations, Rome.

Ferreira M.I., Silvestre J., Conceição N., Malheiro A.C., 2012. Crop and stress coefficients in rainfed and deficit irrigation vineyards using sap flow techniques. Irrig. Sci., 30(5), 433-447.

Field S.K., Smith J.P., Holzapfel B.P., Hardie W.J., Emery R.J.N., 2009. Grapevine response to soil temperature: xylem cytokinins and carbohydrate reserve mobilization from budbreak to anthesis. Am. J. Enol. Vitic., 60(2), 164-172.

Fila G., Di Lena B., Gardiman M., Storchi P., Tornasi D., Silvestroni O., Pitacco A., 2012. Calibration and validation of grapevine budburst models using growth-room experiments as data source. Agric. For. Meteorol., 160, 69-79.

Fraga H., Amraoui M., Malheiro A.C., Moutinho-Pereira J., EirasDias J., Silvestre J., Santos J.A., 2014a. Examining the relationship between the Enhanced Vegetation Index and grapevine phenology. Eur. J. Remote Sens., 47, 753-771. 
Fraga H., Costa R., Moutinho-Pereira J., Correia C.M., Dinis L.-T., Gonçalves I., Silvestre J., Eiras-Dias J., Malheiro A.C., Santos J.A., 2015. Modeling phenology, water status, and yield components of three portuguese grapevines using the STICS crop model. Am. J. Enol. Vitic.: doi:10.5344/ajev.2015.15031.

Fraga H., Malheiro A.C., Moutinho-Pereira J., Cardoso R.M., Soares P.M.M., Cancela J.J., Pinto J.G., Santos J.A., 2014b. Integrated analysis of climate, soil, topography and vegetative growth in Iberian viticultural regions. PLoS One, 9(9), e108078.

Fraga H., Malheiro A.C., Moutinho-Pereira J., Jones G.V., Alves F., Pinto J.G., Santos J.A., 2014c. Very high resolution bioclimatic zoning of Portuguese wine regions: present and future scenarios. Reg. Environ. Change, 14(1), 295-306.

Fraga H., Malheiro A.C., Moutinho-Pereira J., Santos J.A., 2013. Future scenarios for viticultural zoning in Europe: ensemble projections and uncertainties. Int. J. Biometeorol., 57(6), 909-25.

Fraga H., Malheiro A.C., Moutinho-Pereira J., Santos J.A., 2014d. Climate factors driving wine production in the Portuguese Minho region. Agric. For. Meteorol., 185, 26-36.

Fraga H., Santos J.A., Malheiro A.C., Moutinho-Pereira J., 2012. Climate change projections for the Portuguese viticulture using a multi-model ensemble. Ciência Téc. Vitiv., 27(1), 39-48.

Gaudin R., Kansou K., Payan J.C., Pellegrino A., Gary C., 2014. A water stress index based on water balance modelling for discrimination of grapevine quality and yield. J. Int. Sci. Vigne Vin, 48(1), 1-9.

Godwin D., White B., Sommer K., Walker R., Goodwin I., Clingeleffer P., 2002. VineLOGIC e a model of grapevine growth, development and water use. In: Managing Water. 46-50. Dundon, C., Hamilton, R., Johnstone, R., Partridge, S. (eds.), Australian Society of Viticulture and Oenology Inc., Adelaide.

Gonzalez-Camacho J.M., Mailhol J.C., Ruget,F., 2008. Local impact of increasing $\mathrm{CO} 2$ in the atmosphere on maize crop water productivity in the Drome valley, France. Irrig. Drainage, 57(2), 229-243.

Gouveia C., Liberato M.L.R., DaCamara C.C., Trigo R.M., Ramos A.M., 2011. Modelling past and future wine production in the Portuguese Douro Valley. Clim. Res., 48(2), 349-362.

Hardie W.J., Considine J.A., 1976. Response of grapes to waterdeficit stress in particular stages of development. Am. J. Enol. Vitic., 27(2), 55-61.

Hoppmann D., Berkelmann-Loehnertz B., 2000. Prognosis of phenological stages of Vitis vinifera (cv. Riesling) for optimizing pest management*. EPPO Bulletin, 30(1), 121-126.

IPCC, 2013. Climate Change 2013: The Physical Science Basis. Summary for Policymakers. Working Group I Contribution to the IPCC Fifth Assessment Report.

IVV, 2013. Vinhos e Aguardentes de Portugal, Anuário 2013. 236 p. Instituto da Vinha e do Vinho, Lisboa:

Jackson D.I., Lombard P.B., 1993. Environmental and management-practices affecting grape composition and wine quality - a review. Am. J. Enol. Vitic., 44(4), 409-430.

Jego G., Martinez M., Antiguadad I., Launay M., Sanchez-Perez J.M., Justes E., 2008. Evaluation of the impact of various agricultural practices on nitrate leaching under the root zone of potato and sugar beet using the STICS soil-crop model. Sci. Total Environ., 394(2-3), 207-221.

Jones G.V., Davis R.E., 2000. Climate influences on grapevine phenology, grape composition, and wine production and quality for Bordeaux, France. Am. J. Enol. Vitic., 51(3), 249-261.
Jones G.V., Snead N., Nelson P., 2004. Geology and wine 8. Modeling viticultural landscapes: A GIS analysis of the terroir potential in the Umpqua Valley of Oregon. Geosci. Can., 31(4), 167-178.

Jones G.V., White M.A., Cooper O.R., Storchmann K., 2005. Climate change and global wine quality. Clim. Change, 73(3), 319343.

Juin S., Brisson N., Clastre P., Grand P., 2004. Impact of global warming on the growing cycles of three forage systems in upland areas of southeastern France. Agronomie, 24(6-7), 327-337.

Katerji N., Mastrorilli M., Cherni H.E., 2010. Effects of corn deficit irrigation and soil properties on water use efficiency. A 25year analysis of a Mediterranean environment using the STICS model. Eur. J. Agron., 32(2), 177-185.

Kenny G.J., Harrison P.A., 1992. The effects of climate variability and change on grape suitability in Europe. J. Wine Res., 3(3), 163183.

Kose B., 2014. Phenology and ripening of Vitis vinifera L. and Vitis labrusca L. varieties in the maritime climate of Samsun in Turkey's Black Sea region. S. Afr. J. Enol. Vitic., 35(1), 90-102.

Koundouras S., van Leeuwen C., Seguin G., Glories Y., 1999 Influence of water status on vine vegetative growth, berry ripening and wine characteristics in mediterranean zone (example of Nemea, Greece, variety Saint-George, 1997). J. Int. Sci. Vigne Vin, 33, 149160

Kwon E.Y., Jung J.E., Chung U., Yun J.I., Park H.S., 2008. Using thermal time to simulate dormancy depth and bud-burst of vineyards in Korea for the twentieth century. J. Appl. Meteorol. Clim., 47(6), 1792-1801.

Lebon E., Dumas V., Pieri P., Schultz H.R., 2003. Modelling the seasonal dynamics of the soil water balance of vineyards. Funct. Plant Biol., 30(6), 699-710.

Ledoux E., Gomez E., Monget J.M., Viavattene C., Viennot P., Ducharne A., Benoit M., Mignolet C., Schott C., Mary B., 2007. Agriculture and groundwater nitrate contamination in the Seine basin. The STICS-MODCOU modelling chain. Sci. Total Environ., 375(1-3), 33-47.

Leroy P., Smits N., Cartolaro P., Deliere L., Goutouly J.P., Raynal M., Ugaglia A.A., 2013. A bioeconomic model of downy mildew damage on grapevine for evaluation of control strategies. Crop Prot., 53, 58-71.

Lobell D.B., Burke M.B., 2010. On the use of statistical models to predict crop yield responses to climate change. Agric. For. Meteorol., 150(11), 1443-1452.

Lobell D.B., Field C.B., Cahill K.N., Bonfils C., 2006. Impacts of future climate change on California perennial crop yields: Model projections with climate and crop uncertainties. Agric. For. Meteorol., 141(2-4), 208-218.

Lopes J., Eiras-Dias J.E., Abreu F., Climaco P., Cunha J.P., Silvestre J., 2008. Thermal requirements, duration and precocity of phenological stages of grapevine cultivars of the Portuguese collection. Ciência Téc. Vitiv., 23(1), 61-71.

Lopes C., Pinto P.A., 2005. Easy and accurate estimation of grapevine leaf area with simple mathematical models. Vitis, 44(2), 55-61.

Mackenzie, D.E., Christy, A.G., 2005. The role of soil chemistry in wine grape quality and sustainable soil management in vineyards. Wat. Sci. Technol., 51(1), 27-37.

Magalhães N., 2008. Tratado de viticultura: a videira, a vinha e o terroir. 605 p. Chaves Ferreira, Lisboa. 
Malheiro A.C., Campos R., Fraga H., Eiras-Dias J., Silvestre J., Santos J.A., 2013. Winegrape phenology and temperature relationships in the Lisbon Wine Region, Portugal. J. Int. Sci. Vigne Vin, 47(4), 287-299.

Malheiro A.C., Santos J.A., Fraga H., Pinto J.G., 2010. Climate change scenarios applied to viticultural zoning in Europe. Clim. Res., 43(3), 163-177.

McCullagh P., 2002. What is a statistical model? Ann. Stat., 30(5), 1225-1267.

Molitor D., Caffarra A., Sinigoj P., Pertot I., Hoffmann L., Junk J., 2014. Late frost damage risk for viticulture under future climate conditions: a case study for the Luxembourgish winegrowing region. Aust. J. Grape Wine R., 20(1), 160-168.

Moncur M.W., Rattigan K., Mackenzie D.H., Mcintyre G.N., 1989. Base Temperatures for Budbreak and Leaf Appearance of Grapevines. Am. J. Enol. Vitic., 40(1), 21-26.

Moriondo M., Bindi M., Fagarazzi C., Ferrise R., Trombi G., 2011. Framework for high-resolution climate change impact assessment on grapevines at a regional scale. Reg. Environ. Change, 11(3), 553-567.

Moriondo M., Ferrise R., Trombi G., Brilli L., Dibari C., Bindi M., 2015. Modelling olive trees and grapevines in a changing climate. Environ. Model. Software: 1-15. http://dx.doi.org/10.1016/j.envsoft.2014.12.016

Morlat R., Jacquet A., 2003. Grapevine root system and soil characteristics in a vineyard maintained long-term with or without interrow sward. Am. J. Enol. Vitic., 54(1), 1-7.

Muresu M.P., 2012. Impacts of climate change on grapevine: the use of crop model WinStics to estimate potential impacts on grapevine(Vitis vinifera L.) in Sardinia scale. 137 p. PhD Thesis, Universita degli studi di Sassari.

Nemani R.R., White M.A., Cayan D.R., Jones G.V., Running S.W., Coughlan J.C., Peterson D.L., 2001. Asymmetric warming over coastal California and its impact on the premium wine industry. Clim. Res., 19(1), 25-34.

Nendel C., Kersebaum K.C., 2004. A simple model approach to simulate nitrogen dynamics in vineyard soils. Ecol. Model, 177(12), 1-15.

Neumann P.A., Matzarakis A., 2011. Viticulture in southwest Germany under climate change conditions. Clim. Res., 47(3), 161169.

Nicholas K.A., Matthews M.A., Lobell D.B., Willits N.H., Field C.B., 2011. Effect of vineyard-scale climate variability on Pinot noir phenolic composition. Agric. For. Meteorol., 151(12), 15561567.

OIV, 2010. Resolution OIV/VITI 333/2010, definition of vitivinicultural "Terroir", Tbilisi, 25th June 2010.

OIV, 2013. Statistical Report on World Vitiviniculture. 32 p. OIV, Paris.

Oliveira M., 1998. Calculation of budbreak and flowering base temperatures for Vitis vinifera cv. Touriga Francesa in the Douro Region of Portugal. Am. J. Enol. Vitic., 49(1), 74-78.

Parker A., de Cortázar-Atauri I.G., Chuine I., Barbeau G., Bois B., Boursiquot J.-M., Cahurel J.-Y., Claverie M., Dufourcq T., Gény L., Guimberteau G., Hofmann R.W., Jacquet O., Lacombe T., Monamy C., Ojeda H., Panigai L., Payan J.-C., Lovelle B.R., Rouchaud E., Schneider C., Spring J.-L., Storchi P., Tomasi D., Trambouze W., Trought M., van Leeuwen C., 2013. Classification of varieties for their timing of flowering and veraison using a modelling approach: A case study for the grapevine species Vitis vinifera L. Agric. For. Meteorol., 180(0), 249-264.

Parker A.K., de Cortazar-Atauri I.G., van Leeuwen C., Chuine I., 2011. General phenological model to characterise the timing of flowering and veraison of Vitis vinifera L. Aust. J. Grape Wine R., 17(2), 206-216.

Paz J.O., Fraisse C.W., Hatch L.U., Garcia A.Y.G., Guerra L.C., Uryasev O., Bellow J.G., Jones J.W., Hoogenboom G., 2007. Development of an ENSO-based irrigation decision support tool for peanut production in the southeastern US. Comput. Electron. Agric., 55(1), 28-35.

Pellegrino A., Clingeleffer P., Cooley N., Walker R., 2014 Management practices impact vine carbohydrate status to a greater extent than vine productivity. Front. Plant Sci., 5, 283.

Pellegrino A., Gozé E., Lebon E., Wery J., 2006. A model-based diagnosis tool to evaluate the water stress experienced by grapevine in field sites. Eur. J. Agron., 25(1), 49-59.

Pellegrino A., Lebon E., Simonneau T., Wery J., 2005. Towards a simple indicator of water stress in grapevine (Vitis vinifera L.) based on the differential sensitivities of vegetative growth components. Aust. J. Grape Wine R., 11(3), 306-315.

Pinto P.A., 2013. Agricultura e incerteza climática, Personal comunication, Seminar: Alterações climáticas em viticultura SIAMVITI.

Poni S., Palliotti A., Bernizzoni F. 2006. Calibration and evaluation of a STELLA software-based daily CO2 balance model in Vitis vinifera L. J. Am. Soc. Hortic. Sci., 131(2), 273-283.

Quiroga S., Iglesias A., 2009. A comparison of the climate risks of cereal, citrus, grapevine and olive production in Spain. Agric. Sys., 101(1-2), 91-100.

Real A.C., Borges J., Cabral J.S., Jones G.V., 2014. Partitioning the grapevine growing season in the Douro Valley of Portugal: accumulated heat better than calendar dates. Int. J. Biometeorol.: 1-

Rodrigues A., Marcal A.S., Cunha M., 2013. Monitoring vegetation dynamics inferred by satellite data using the PhenoSat tool. IEEE T. Geosci. Remote Sens., 51(4), 2096-2104.

Rodriguez J.C., Duchemin B., Hadria R., Watts C., Garatuza J., Chehbouni A., Khabba S., Boulet G., Palacios E., Lahrouni A., 2004. Wheat yield estimation using remote sensing and the STICS model in the semiarid Yaqui valley, Mexico. Agronomie, 24(6-7), 295-304.

Roux S., Brun F., Wallach D., 2014. Combining input uncertainty and residual error in crop model predictions: A case study on vineyards. Eur. J. Agron., 52, 191-197.

Rovira-Más F., Sáiz-Rubio V., 2013. Crop biometric maps: the key to prediction. Sensors, 13(9), 12698-12743.

Ruiz-Ramos M., Gabriel J.L., Vazquez N., Quemada M., 2011. Evaluation of nitrate leaching in a vulnerable zone: effect of irrigation water and organic manure application. Span. J. Agric. Res., 9(3), 924-937.

Salinari F., Mariani L., Poni S., Cola G., Bettati T., Diago M.P., Tardaguila J., Oliveira M., 2014. Development of a water stress alert system embedded in a DSS for integrated vineyard management. In: VII International Symposium on Irrigation of Horticultural Crops, 1038, 565-572.

Santos J.A., Grätsch S.D., Karremann M.K., Jones G.V., Pinto J.G., 2013. Ensemble projections for wine production in the Douro Valley of Portugal. Clim. Change, 117(1-2), 211-225. 
Santos J.A., Malheiro A.C., Karremann M.K., Pinto J.G., 2011. Statistical modelling of grapevine yield in the Port Wine region under present and future climate conditions. Int. J. Biometeorol., 55(2), 119-31.

Santos J.A., Malheiro A.C., Pinto J.G., Jones G.V., 2012. Macroclimate and viticultural zoning in Europe: observed trends and atmospheric forcing. Clim. Res., 51(1), 89-103.

Scaglione G., Pasquarella C., Federico R., Bonfante A., Terribile F., 2008. A multidisciplinary approach to grapevine zoning using GIS technology: An example of thermal data elaboration. Vitis, 47(2), 131-132.

Schreiner R.P., Lee J., 2014. Effects of post-veraison water deficit on 'pinot noir' yield and nutrient status in leaves, clusters, and musts. HortScience, 49(10), 1335-1340

Schultz H.R., 1992. An empirical-model for the simulation of leaf appearance and leaf-area development of primary shoots of several grapevine (Vitis vinifera L.) canopy-systems. Sci. Hort., 52(3), 179200.

Semenov M.A., Doblas-Reyes F.J., 2007. Utility of dynamical seasonal forecasts in predicting crop yield. Clim. Res., 34(1), 7181.

Shin D.W., Baigorria G.A., Lim Y.-K., Cocke S., LaRow T.E., O'Brien J.J., Jones J.W., 2009. Assessing crop yield simulations with various seasonal climate data. Science and Technology Infusion Climate Bulletin. NOAA's National Weather Service.

Stock M., Gerstengarbe F.W., Kartschall T., Werner P.C., 2005. Reliability of climate change impact assessments for viticulture. Acta Hortic., 689, 29-39.

Storchi P., Costantini E.A.C., Bucelli P., 2005. The influence of climate and soil on viticultural and enological parameters of 'Sangiovese' grapevines under non-irrigated conditions. In: Proceedings of the Seventh International Symposium on Grapevine Physiology and Biotechnology, 689, 333-340.

Tomasi D., Jones G.V., Giust M., Lovat L., Gaiotti F., 2011. Grapevine phenology and climate change: relationships and trends in the Veneto Region of Italy for 1964-2009. Am. J. Enol. Vitic., 62(3), 329-339.

Tournebize J., Kao C., Nikolic N., Zimmer D., 2004. Adaptation of the STICS model to subsurface drained soils. Agronomie, 24(6-7), 305-313.

Trought M.C.T., Howell G.S., Cherry N., 1999. Practical considerations for reducing frost damage in vineyards. Report to New Zealand Winegrowers, New Zealand Winegrowers, Auckland.

Unwin P.T.H., 1996. Wine \& The Vine. 415 p. Routledge, London.

Valade A., Vuichard N., Ciais P., Ruget F., Viovy N., Gabrielle B., Huth N., Martine J.F., 2014. ORCHIDEE-STICS, a process-based model of sugarcane biomass production: calibration of model parameters governing phenology. Gcb. Bioenergy, 6(5), 606-620.
Valdes-Gomez H., Brisson N., Acevedo-Opazo C., Ortega-Farias S., Gary C., 2011. Modelling the effects of Nino and Nina events on water balance of grapevine ('Cabernet Sauvignon') in Central Valley of Chile. Vi International Symposium on Irrigation of Horticultural Crops, 889: 159-166.

Valdes-Gomez H., Celette F., de Cortazar-Atauri I.G., Jara-Rojas F., Ortega-Farias S., Gary C., 2009. Modelling soil water content and grapevine growth and development with the Stics crop-soil model under two different water management strategies. J. Int. Sci. Vigne Vin, 43(1), 13-28.

van Leeuwen C., Friant P., Choné X., Tregoat O., Koundouras S. Dubordieu D., 2004. Influence of climate, soil, and cultivar on terroir. Am. J. Enol. Vitic., 55(3), 207-217.

van Leeuwen C., Garnier C., Agut C., Baculat B., Barbeau G., Besnard E., Bois B., Boursiquot J.-M., Chuine I., Dessup T., Dufourcq T., Garcia-Cortazar I., Marguerit E., Monamy C. Koundouras S., Payan J.-C., Parker A., Renouf V., RodriguezLovelle B., Roby J.-P., Tonietto J., Trambouze W., 2008. Heat requirements for grapevine varieties is essential information to adapt plant material in a changing climate. In: Proceedings of the 7th International Terroir Congress, 222-227.

van Vaudour E., Carey V.A., Gilliot J.M., 2010. Digital zoning of South African viticultural terroirs using bootstrapped decision trees on morphometric data and multitemporal SPOT images. Remote Sens. Environ., 114(12), 2940-2950.

Webb L.B., Whetton P.H., Barlow E.W.R., 2007. Modelled impact of future climate change on the phenology of winegrapes in Australia. Aust. J. Grape Wine R., 13(3), 165-175.

Webb L.B., Whetton P.H., Barlow E.W.R., 2008a. Climate change and winegrape quality in Australia. Clim. Res., 36, 99-111.

Webb L.B., Whetton P.H., Barlow,E.W.R., 2008b. Modelling the relationship between climate, winegrape price and winegrape quality in Australia. Clim. Res., 36(2), 89-98.

Williams D.W., Williams L.E., Barnett W.W., Kelley K.M., McKenry M.V., 1985. Validation of a model for the growth and development of the Thompson seedless grapevine .1. Vegetative growth and fruit yield. Am. J. Enol. Vitic., 36(4), 275-282.

Winkler A.J., 1974. General viticulture. University of California Press, California.

Yau I.H., Davenport J.R., Rupp R.A., 2013. Characterizing inland Pacific Northwest American viticultural areas with geospatial data. PLoS One, 8(4), e61994.

Zsofi Z., Toth E., Rusjan D., Balo B., 2011. Terroir aspects of grape quality in a cool climate wine region: Relationship between water deficit, vegetative growth and berry sugar concentration. Sci. Hort., 127(4), 494-499. 